\title{
ANALISIS PERIODE ULANG DAN AKTIVITAS KEGEMPAAN PADA DAERAH SUMATERA BARAT DAN SEKITARNYA
}

\author{
Arif Budiman', Riva Nandia', dan Moh. Taufik Gunawan ${ }^{2}$ \\ 1 Laboratorium Fisika Bumi Jurusan Fisika Fakultas Matematika dan Ilmu \\ Pengetahuan Alam Universitas Andalas Kampus Limau Manis Padang, \\ Sumatera Barat, 25163 Telp: 081363152952, \\ Email: arifbudiman@fmipa.unand.ac.id \\ 2 \\ Stasiun Geofisika Jl. Sultan Syahrir Silaing Bawah, Padang Panjang, \\ Sumatera Barat
}

\begin{abstract}
ABSTRAK
Analisis keaktifan dan periode ulang gempa bumi berdasarkan magnitudo telah dilakukan pada empat daerah penelitian di daerah Sumatera Barat dan sekitarnya. Keempat daerah tersebut adalah segmen Siberut (daerah I), daerah antara segmen Siberut dan Padang (daerah II), segmen Pagai (daerah III) dan daerah antara segmen Pagai dan Muko-Muko (daerah IV). Data yang digunakan adalah data gempa bumi dengan magnitudo sama atau besar dari 5,0 Skala Richter dan kedalaman 0-300 km pada periode tahun 1973- 2010 yang bersumber dari USGS (United State Geological Service). Tingkat keaktifan gempa bumi (nilai $a$ dan $b$ ) dan nilai periode ulang dihitung menggunakan metode Likelihood. Dari perhitungan aktivitas kegempaan untuk keempat daerah diperoleh nilai $a$ berkisar dari 6,70 sampai 7,13 dan nilai $b$ berkisar dari 0,94 sampai 1,01 . Hal ini menunjukkan bahwa keempat daerah penelitian mempunyai aktivitas kegempaan yang relatif hampir sama. Dari perhitungan periode ulang, magnitudo 5,0-6,5 SR memadai dijadikan acuan dalam memperkirakan perulangan gempa untuk keempat daerah penelitian. Tetapi untuk gempagempa besar (daerah I gempa besar dari 7,5 SR, daerah II gempa besar dari 6,5 SR, daerah III dan IV gempa besar dari 7,0 SR), diperkirakan tidak akan terjadi karena mengingat keempat daerah merupakan daerah dengan aktivitas kegempaan yang cukup tinggi karena terletak di daerah dan sekitar zona subduksi.
\end{abstract}

Kata kunci: aktivitas kegempaan, periode ulang. dan metode Likelihood.

\begin{abstract}
An analysis of activity and periodicity prediction of earthquake based on magnitude in four research areas in West Sumatera and surroundings had been done. Four of the research areas are segment of Siberut (area I), region of between segment of Siberut and Padang (area II), segment of Pagai (area III) dan region of between segment of Pagai and Muko-Muko (area IV). The earthquake data that were analyzed are the ones which are equal and more than 5.0 SR, depth 0$300 \mathrm{~km}$ and happened in 1973-2010 (taken from USGS (United State Geological Service)). The value activity of earthquake ( $a$ and $b$ value) of periodicity prediction of earthquake have been conducted by using Likelihood method. From the calculation of earthquake activity for the four research area have been got that the value of $a$ between 6.70 and 7.13 and the value of $b$ between 0.94 and 1.01. This result show that earthquake activity for the four research are relatively same. From the calculation of periodicity prediction of earthquake, the magnitude of 5.0-6.5 SR are sufficient to be reference of periodicity prediction of earthquake for the that areas, but there would be no earthquake with bigger magnitude (7.5 SR for area I, 6.5 for area II, 7.0 SR for area III and IV) happened to that areas. The earthquake activity of four research areas is relatively high because they are located around the subduction zone.
\end{abstract}

Keywords : activity of earthquake, likelihood method, periodicity prediction 


\section{PENDAHULUAN}

Gempa bumi yang terjadi di daerah Sumatera Barat, diakibatkan oleh pergeseran lempeng Eurasia ke arah Selatan dan lempeng Indo Australia ke arah Utara serta adanya sistem sesar Sumatera yang memanjang dari Aceh sampai teluk Semangko di Lampung (Gunawan, 2000). Hal ini yang menyebabkan Sumatera Barat dan sekitarnya memiliki tingkat kerawanan terhadap gempa bumi cukup tinggi.

Beberapa kejadian gempa yang terjadi adalah gempa bumi dalam skala besar. Gempa besar tersebut menimbulkan kerusakan pada suatu daerah yang mengakibatkan banyak korban jiwa dan harta benda dalam waktu singkat. Hingga saat ini gempa yang terjadi secara tiba-tiba dan masih sulit untuk diprediksi. Oleh karena itu, perlu metode untuk memprediksi gempa bumi sehingga masyarakat dapat bersiaga untuk menghadapi gempa bumi.

Metode yang biasa digunakan untuk memprediksi gempa adalah seismogeological, statistic analysis of seismicity, correlation analysis dan metode precursor (Ismail, 2010). Ada juga metode geokimia yaitu melihat kandungan logam dalam tanah. Salah satu dari metode statistic analysis of seismicity adalah periode ulang. Periode ulang gempa bumi diperoleh dengan mengetahui nilai parameter keaktifan gempa bumi yaitu $a$ menyatakan keadaan seimisitas dan $b$ menyatakan keadaan tektonik. Metoda yang dapat digunakan untuk menghitung parameter keaktifan gempa bumi salah satunya adalah metode Likelihood. Metoda ini mempunyai keunggulan, dimana dalam menghitung secara statistik nilai parameter keaktifan gempa bumi, kelas interval magnitudo dapat diatur sedemikian rupa untuk menghindari kekosongan magnitudo pada kelas interval tertentu.

Dalam metoda Likelihood, nilai $a$ dan $b$ dapat diperoleh dari persamaan berikut :

$$
b=\frac{\log e}{\bar{M}-M_{0}}
$$

dan

$$
a=\log N+\log b \ln 10+M_{0} b
$$

dengan $\bar{M}$ adalah magnitudo rata-rata gempa, $M_{0}$ adalah magnitudo minimum dan $N$ adalah jumlah gempa dengan magnitudo lebih atau sama dengan 5,0 SR ( $M \geq 5 \mathrm{SR})$.

Menurut Peter (1965) indeks seismisitas gempa dengan magnitudo besar atau sama dengan 5,0 SR $\left(N_{1}(M \geq 5)\right)$ menggambarkan total kejadian gempa bumi rata-rata pertahun dan dapat ditentukan berdasarkan persamaan berikut

$$
N_{1}(M \geq 5)=10^{a^{\prime}-5 b}
$$

dengan $a^{\prime}=a-\log (b \ln 10)$. Selanjutnya periode ulang gempa bumi $(\theta)$ dalam satuan tahun dan ditentukan menggunakan persamaan berikut

$$
\theta=\frac{1}{N_{1}(M \geq 5)}
$$

Beberapa peneliti telah melakukan penelitian tentang periode ulang gempa yaitu Isnaini (2006) dan Lora (2009). Kedua peneliti ini melakukan penelitian untuk menentukan periode ulang gempa bumi berdasarkan kedalamannya yaitu kecil dari $60 \mathrm{~km}$ dan 
kedalaman antara $60 \mathrm{~km}$ sampai $300 \mathrm{~km}$. Pada penelitian ini, periode ulang gempa bumi ditentukan berdasarkan magnitudonya untuk wilayah Sumatera Barat dan sekitarnya.

Hasil dari penelitian ini diharapkan mendapatkan gambaran aktivitas gempa bumi daerah subduksi Sumatera Barat, periode ulang gempa dan waktu terjadinya gempa bumi bisa diprediksi. Sehingga masyarakat dapat mereduksi efek dari gempa bumi tersebut.

\section{METODE PENELITIAN}

Dalam penelitian data dilakukan beberapa langkah-langkah sistematis sebagai berikut:

1. Mengambil seluruh data gempa bumi dari tahun 1973-2010 daerah Sumatera Barat dan sekitarnya dari USGS (United State Geological Service) dengan $M \geq 5$ SR dan kedalaman $0-300 \mathrm{~km}$.

2. Memplot semua data gempa bumi ke dalam peta daerah Sumatera Barat dan sekitarnya dengan program Win ITDB dan Arc View Gis 3.2.

3. Membagi daerah penelitian dengan melihat penyebaran gempa bumi yang terjadi pada daerah Sumatera Barat.

4. Menentukan hubungan frekuensi atau jumlah gempa bumi dengan cara membuat kelas interval magnitudo dengan jumlah gempa bumi.

5. Menghitung harga $b$ dan $a$ dengan menggunakan persamaan (1) dan (2).

6. Menentukan indeks seismisitas dengan menggunakan persamaan (3) dan periode ulang dengan menggunakan persamaan (4).

7. Menganalisis periode ulang gempa berdasarkan interval magnitudo.

\section{HASIL}

Dari penyebaran gempa, daerah penelitian dibagi menjadi empat daerah yang dapat dilihat pada Gambar 1. Posisi koordinat geografis daerah penelitian dapat dilihat pada Tabel 1. Hasil perhitungan parameter keaktifan gempa bumi ditunjukkan pada Tabel 2 dan indeks seismisitas dan periode ulang gempa bumi pada empat daerah ditunjukkan pada Tabel 3 .

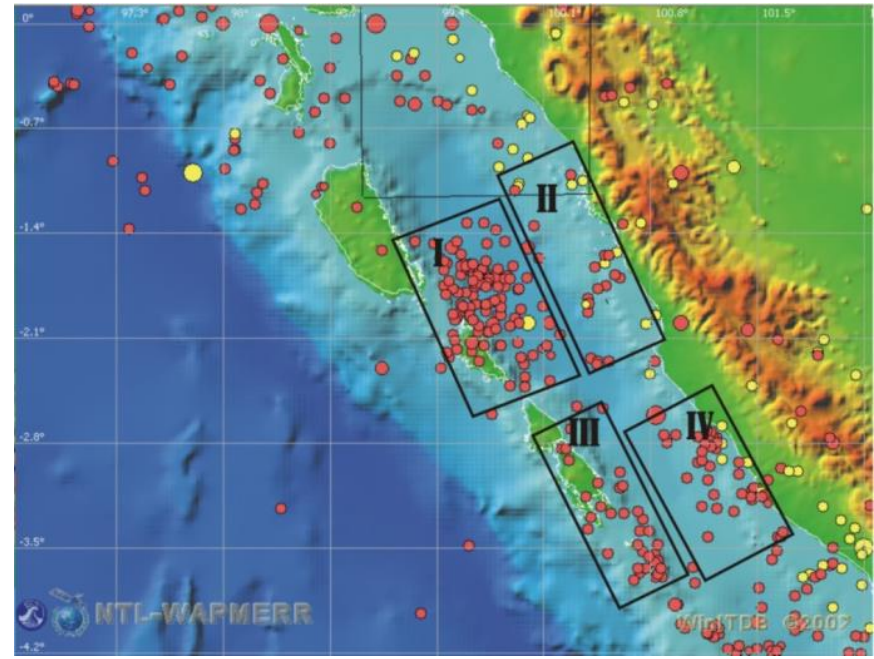

Gambar 1. Peta daerah penelitian 
Tabel 1. Posisi koordinat geografis daerah penelitian.

\begin{tabular}{|c|c|c|c|}
\hline No. & Daerah & Koordinat Geografis & Keterangan \\
\hline 1 & Daerah I & $\begin{array}{c}\left(1,45^{0} \mathrm{LS} ; 99^{0} \mathrm{BT}\right) ;\left(1,2^{0} \mathrm{LS} ; 99,7^{0} \mathrm{BT}\right) \\
\left(2,6^{0} \mathrm{LS} ; 99,6^{0} \mathrm{BT}\right) ;\left(2,4^{0} \mathrm{LS} ; 100,3^{0} \mathrm{BT}\right)\end{array}$ & Segmen Siberut \\
\hline 2 & Daerah II & $\begin{array}{c}\left(1,2^{0} \mathrm{LS} ; 99,7^{0} \mathrm{BT}\right) ;\left(0,8^{0} \mathrm{LS} ; 100,3^{0} \mathrm{BT}\right) \\
\left(2,4^{0} \mathrm{LS} ; 100,4^{0} \mathrm{BT}\right) ;\left(2,1^{0} \mathrm{LS} ; 100,9^{0} \mathrm{BT}\right)\end{array}$ & $\begin{array}{c}\text { Antara segmen Siberut } \\
\text { dan Padang }\end{array}$ \\
\hline 3 & Daerah III & $\begin{array}{c}\left(2,7^{0} \mathrm{LS} ; 100^{0} \mathrm{BT}\right) ;\left(2,5^{0} \mathrm{LS} ; 100,4^{0} \mathrm{BT}\right) \\
\left(3,8^{0} \mathrm{LS} ; 100,4^{0} \mathrm{BT}\right) ;\left(3,7^{0} \mathrm{LS} ; 101^{0} \mathrm{BT}\right.\end{array}$ & $\begin{array}{c}\text { Segmen Pagai } \\
\end{array}$ \\
\hline 4 & Daerah IV & $\begin{array}{c}\left(2,7^{0} \mathrm{LS} ; 100,6^{0} \mathrm{BT}\right) ;\left(2,5^{0} \mathrm{LS} ; 101,3^{0} \mathrm{BT}\right) \\
\left(3,7^{0} \mathrm{LS} ; 101,2^{0} \mathrm{BT}\right) ;\left(3,4^{0} \mathrm{LS} ; 101,7^{0} \mathrm{BT}\right.\end{array}$ & $\begin{array}{c}\text { Antara segmen Pagai } \\
\text { dan Muko-Muko. }\end{array}$ \\
\hline
\end{tabular}

Tabel 2. Parameter keaktifan daerah penelitian.

\begin{tabular}{|c|c|c|c|}
\hline No. & Daerah Penelitian & $\boldsymbol{a}$ & $\boldsymbol{b}$ \\
\hline 1 & Daerah I & 7,13 & 1,01 \\
\hline 2 & Daerah II & 6,12 & 0,97 \\
\hline 3 & Daerah III & 7,00 & 1,01 \\
\hline 4 & Daerah IV & 6,70 & 0,94 \\
\hline
\end{tabular}

Tabel 3. Indeks seismisitas dan periode ulang daerah penelitian.

\begin{tabular}{|c|c|c|c|c|c|c|c|c|c|}
\hline \multirow{2}{*}{$\begin{array}{l}\mathbf{N} \\
\mathbf{0}\end{array}$} & \multirow{2}{*}{$\begin{array}{l}\text { Mag. } \\
\text { (SR) }\end{array}$} & \multicolumn{2}{|c|}{ Daerah I } & \multicolumn{2}{|c|}{ Daerah II } & \multicolumn{2}{|c|}{ Daerah III } & \multicolumn{2}{|c|}{ Daerah IV } \\
\hline & & $\begin{array}{c}\mathrm{N}_{1} \\
\left(\mathrm{Thn}^{-1}\right)\end{array}$ & $\begin{array}{c}\theta \\
\text { (Thn) }\end{array}$ & 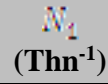 & $\begin{array}{c}\theta \\
\text { (Thn) }\end{array}$ & $\begin{array}{c}\left(\mathrm{Thn}_{1}{ }^{-1}\right) \\
\text { (1) }\end{array}$ & $\begin{array}{c}\theta \\
\text { (Thn) }\end{array}$ & $\begin{array}{c}N_{1} \\
\left(T_{h n} n^{-1}\right)\end{array}$ & $\begin{array}{c}\theta \\
\text { (Thn) }\end{array}$ \\
\hline 1 & $5,0-5,4$ & 50,00000 & 0,02 & 0,12500 & 8,00 & 33,33333 & 0,03 & 50,00000 & 0,02 \\
\hline 2 & $5,5-5,9$ & 16,66667 & 0,06 & 0,04000 & 25,00 & 12,50000 & 0,08 & 16,66667 & 0,06 \\
\hline 3 & $6,0-6,4$ & 5,00000 & 0,20 & 0,01000 & 100,00 & 3,70370 & 0,27 & 5,00000 & 0,20 \\
\hline 4 & $6,5-6,9$ & 1,56250 & 0,64 & 0,00400 & 250,00 & 1,25000 & 0,80 & 1,78571 & 0,56 \\
\hline 5 & $7,0-7,4$ & 0,50000 & 2,00 & 0,00100 & 1000,00 & 0,37037 & 2,70 & 0,62500 & 1,60 \\
\hline 6 & 7,5-7,9 & 0,15152 & 6,60 & 0,00040 & 2500,00 & 0,11628 & 8,60 & 0,20000 & 5,00 \\
\hline 7 & $8,0-8,4$ & 0,04000 & 25,00 & 0,00020 & 5000,00 & 0,03597 & 27,80 & 0,06757 & 14,80 \\
\hline 8 & $8,5-8,9$ & 0,01515 & 66,00 & 0,00005 & 20000,00 & 0,01000 & 100,00 & 0,02000 & 50,00 \\
\hline 9 & $9,0-9,4$ & 0,00461 & 217,00 & 0,00002 & 50000,00 & 0,00300 & 333,30 & 0,00800 & 125,00 \\
\hline
\end{tabular}

\section{DISKUSI}

Dari Tabel 2 terlihat bahwa nilai $a$ (keadaan seismisitas) berkisar dari 6,70 sampai dengan 7,13 dan nilai $b$ (keadaan tektonik) berkisar dari 0,94 sampai 1,01. Jika dibandingkan antar daerah penelitian, perbedaan nilai $a$ maupun nilai $b$ tersebut tidak signifikan. Hal ini menunjukkan bahwa keempat daerah penelitian memiliki keadaan seismisitas dan tektonik yang hampir sama. Untuk daerah I dan III memiliki nilai $a$ dan $b$ sedikit lebih besar dibandingkan daerah II dan IV. Ini berarti daerah I dan III mempunyai aktifitas kegempaan sedikit lebih tinggi dibandingkan daerah II dan IV. Hal ini disebabkan karena daerah I dan III terletak pada daerah subduksi. Daerah subduksi adalah daerah pertemuan dua lempeng dimana salah satu lempeng menunjam ke dalam lempeng yang lainnya, yaitu Lempeng Indo-Australia dan Lempeng Eurasia. Tetapi walau bagaimanapun daerah II dan IV masih terletak di sekitar daerah subduksi, hal inilah yang menyebabkan baik perbandingan nilai $a$ maupun $b$ tidak terlalu signifikan untuk keempat daerah. Sehingga 
jika ditinjau secara keseluruhan keempat daerah penelitian mempunyai aktivitas kegempaan yang relatif hampir sama, hal ini menunjukkan bahwa untuk daerah perairan Sumatera Barat dan sekitarnya mempunyai aktivitas kegempaan yang relatif hampir sama.

Berdasarkan Tabel 3 dapat dilihat bahwa pada daerah I dengan skala 5,0-5,4 SR nilai indeks seismisitasnya paling besar diantara daerah lainnya yaitu 51,2 artinya rata-rata pertahun gempa terjadi sebanyak 51 kali dan periode ulangnya 0,02 tahun ( 7 hari). Skala 5,5-5,9 SR nilai indeks seismisitasnya juga lebih besar yaitu 16 artinya rata-rata pertahun gempa terjadi sebanyak 16 kali dan periode ulangnya 0,06 tahun (22 hari). Skala 6,0-6,4 SR nilai indeks seismisitasnya didapatkan 5 artinya rata-rata pertahun gempa terjadi sebanyak 5 kali dan periode ulangnya 0,2 tahun (2,4 bulan). Skala 6,5-6,9 SR nilai indeks seismisitasnya didapatkan 1,56 artinya rata-rata pertahun gempa terjadi sebanyak 2 kali dan periode ulangnya 0,64 tahun (7,7 bulan). Skala 7,0-7,4 SR nilai indeks seismisitasnya didapatkan 0,48 dan periode ulangnya 2 tahun.

Berdasarkan data gempa yang diambil dari tahun 1973-2010 (37 tahun) magnitudo maksimum yang pernah terjadi pada daerah I hanya 1 kali yaitu skala 7,0 SR pada tanggal 13 Septemper 2007 dari perhitungan diprediksikan akan terjadi kembali pada tahun 2009, tetapi tidak terjadi. Skala 7,5-7,9 SR nilai indeks seismisitasnya didapatkan 0,15 dan periode ulangnya 6,6 tahun, dari data gempa dalam waktu 37 terakhir ini belum pernah terjadi. Hal ini menunjukkan bahwa gempa dengan magnitudo lebih dari 7,5 SR tidak akan pernah terjadi pada daerah I. Daerah I tergolong daerah yang aktif dari segi kegempaan karena terletak dekat daerah subduksi, maka sering terjadi gempa berskala kecil (gempa paling besar 7,0 SR). Hal ini dimungkinkan karena daerah ini merupakan daerah yang aktif dari segi kegempaan, maka pelepasan energi berlangsung terus menerus, sehingga diperkirakan tidak terjadi pelepasan energi dalam skala sangat besar yang menyebabkan gempa sangat besar dalam hal ini gempa dengan magnitudo besar dari 7,5 SR.

Pada daerah II dengan skala 5,0-5,4 SR didapatkan nilai indeks seismisitasnya 0,12 artinya rata-rata terjadi sebanyak 1 kali dalam sepuluh tahun dan periode ulangnya 8 tahun. Skala 5,5-5,9 SR didapatkan nilai indeks seismisitasnya 0,04 artinya rata-rata terjadi sebanyak 4 kali dalan seratus tahun dan periode ulangnya 25 tahun. Dari hasil perhitungan gempa dengan magnitudo 6,0-6,4 diperoleh indeks seimisitasnya 0,01 dan periode ulangnya 100 tahun.

Berdasarkan data gempa dari tahun 1973-2010 (37 tahun) pada daerah II skala gempa terbesarnya 6,0 SR, dan terjadi sebanyak 2 kali yaitu pada tanggal 22 Februari 2004 dan tanggal 25 Nopember 2007. Hai ini menunjukkan perulangan gempa 6,0 SR terjadi 2 kali dalam kurun 37 tahun. Jadi kemungkinan terjadi gempa dengan magnitudo 6,0-6,4 SR bisa terjadi kurang dari 100 tahun. Selanjutnya untuk gempa dengan magnitudo besar dari 6,5 diperkirakan tidak akan pernah terjadi untuk daerah II ini, dengan alasan yang sama untuk daerah I (daerah II memiliki tingkat kegempaan yang relatif hampir sama dengan daerah I). Walaupun dari segi perhitungan masih bisa terjadi, dalam kurun waktu yang lama.

Pada daerah III dengan skala 5,0-5,4 SR didapatkan nilai indeks seismisitasnya 39,9 artinya rata-rata pertahun terjadi sebanyak 40 kali dan periode ulangnya 0,025 tahun $(9$ hari). Skala 5,5-5,9 SR nilai indeks seismisitasnya didapatkan 12,16 artinya rata-rata pertahun gempa terjadi sebanyak 12 kali dan periode ulangnya 0,08 tahun ( 29 hari). Skala 6,0-6,4 SR nilai indeks seismisitasnya didapatkan 3,8 artinya rata-rata pertahun gempa terjadi sebanyak 4 kali dan periode ulangnya 0,27 tahun (3 bulan). Skala 6,5-6,9 SR nilai indeks seismisitasnya didapatkan 1,2 artinya rata-rata pertahun terjadi 1 kali dan periode ulangnya 0,8 tahun $(9,6$ bulan). 
Berdasarkan data gempa yang diambil dari tahun 1973-2010 (37 tahun) magnitudo maksimum yang pernah terjadi pada daerah III hanya 1 kali yaitu skala 6,8 SR pada tanggal 5 Maret 2010 dan diprediksikan akan terjadi pada tahun 2011 karena periode ulangnya 0,8 tahun (sekitar 9 bulan). Dengan alasan yang sama dengan kedua daerah sebelumnya (daerah III memiliki tingkat kegempaan yang relatif hampir sama dengan daerah I dan II), gempa dengan magnitudo lebih dari 7,0 SR kemungkinan tidak pernah terjadi untuk daerah III ini. Walaupun dari segi perhitungan masih dapat terjadi, dalam kurun waktu yang lama.

Pada daerah IV dengan skala 5,0-5,4 SR didapatkan nilai indeks seismisitasnya 45,7 artinya rata-rata pertahun terjadi sebanyak 46 kali dan periode ulangnya 0,02 tahun (7 hari). Skala 5,5-5,9 SR nilai indeks seismisitasnya didapatkan 15,4 artinya rata-rata pertahun gempa terjadi sebanyak 15 kali dan periode ulangnya 0,06 tahun ( 22 hari). Skala 6,0-6,4 SR nilai indeks seismisitasnya didapatkan 5,2 artinya rata-rata pertahun gempa terjadi sebanyak 5 kali dan periode ulangnya 0,2 tahun (2,4 bulan). Skala 6,5-6,9 SR nilai indeks seismisitasnya didapatkan 1,78 artinya rata-rata pertahun terjadi 2 kali dan periode ulangnya 0,56 tahun $(6,7$ bulan).

Mengacu pada data gempa yang diambil dari tahun 1973-2010 (37 tahun) magnitudo maksimum yang pernah terjadi pada daerah IV hanya 1 kali yaitu skala 6,6 SR pada tanggal 1 Oktober 2009 dan diprediksikan akan terjadi pada lagi sekitar April atau Mei tahun 2010. Dengan alasan yang sama dengan ketiga daerah sebelumnya (daerah IV memiliki tingkat kegempaan yang relatif hampir sama dengan daerah I, II dan III), gempa dengan magnitudo lebih dari 7,0 SR kemungkinan tidak pernah terjadi untuk daerah IV ini. Walaupun dari segi perhitungan masih bisa terjadi, dalam kurun waktu yang lama.

Berdasarkan penjelasan di atas dapat disimpulkan bahwa untuk keempat daerah tersebut memiliki nilai indeks seismisitas dan periode ulangnya yang sama. Pada magnitudo 5 SR sampai 6,9 SR bisa dijadikan sebagai acuan dalam memprediksi gempa selanjutnya pada keempat daerah. Sementara itu, gempa dengan magnitudo 7 SR sampai 9 SR diprediksikan tidak akan pernah terjadi dalam kurun waktu yang singkat pada keempat daerah ini. Menurut perhitungan gempa dengan magnitudo 7 SR sampai 9 SR bisa terjadi pada keempat daerah ini dalam kurun waktu yang lama.

\section{KESIMPULAN}

Berdasarkan analisis dan hasil pengolahan data dapat disimpulkan bahwa, nilai parameter aktivitas gempa bumi dari empat daerah penelitian diperoleh nilai $a$ yang bervariasi antara 6,7 sampai 7,13 dan nilai $b$ bervariasi antara 0,94 sampai 1,01. Hal ini menunjukkan bahwa keempat daerah penelitian mempunyai aktivitas kegempaan yang relatif hampir sama.

Berdasarkan perhitungan diperoleh bahwa perulangan gempa dengan magnitudo 5,0-6,5 SR untuk keempat daerah penelitian cukup bisa dijadikan acuan dalam memperkirakan perulangan gempa. Tetapi untuk gempa-gempa besar (daerah I gempa besar dari 7,5 SR, daerah II gempa besar dari 6,5 SR, daerah III dan IV gempa besar dari 7,0 SR), diperkirakan tidak akan terjadi karena mengingat keempat daerah merupakan daerah dengan aktivitas kegempaan yang cukup tinggi karena terletak di daerah dan sekitar zona subduksi.

\section{DAFTAR PUSTAKA}

1. Gunawan, M.T. dan Wandono, 2000, Tinjauan Statistik Resiko Gempa bumi di Indonesia Year Book Mitigasi Bencana 2000, BMG, Jakarta. 
2. Ibrahim, G. dan Subardjo, 2000, Buku Seismologi, BMG, Jakarta.

3. Ismail, S., 1989, Pendahuluan Seismologi, Balai Diklat Meteorologi dan Geofisika Balai Pendidikan dan Pelatihan Departemen Perhubungan, Jakarta.

4. Ismail, S., 1989, Seismik Refraksi Terapan, Balai Diklat Meteorologi dan Geofisika Balai Pendidikan dan Pelatihan Departemen Perhubungan, Jakarta.

5. Isnaini, A.V., 2006, Penentuan Tingkat Kegempaan dan Prakiraan Periode Ulang Gempa Tektonik Di Sumatera Barat, UNAND, Padang.

6. Lora, Y., 2010, Analisis Aktivitas dan Periode Ulang Gempa Bumi Daerah Siberut Sumatera Barat Menggunakan Metode Likelihood, UNP, Padang.

7. Peter, W.M., 1926-1956, Statistical Analysis of Earthquake Occurrence in Japan, BIISEE. Vol. 2 (1965), pp. 1-27.

8. Soedarmo, D., 1897 - 1973, Statistical Analysis of The Earthquakes Occurence And Seismic Activity in Some Of The Indonesian Region.

9. Walker, P. M., 1965, Statistical Analysis of Earthquake Occurance in Japan, Bulletin Of The International Institute Of Seismology And earthquake Engineering 2, pp-1-27.

10. Young, H. D., 1962, Statistical Treatment Of Experimental Dat, Mc Graw-Hill Book Company, USA. 